Article

\title{
Spatial-Temporal Variation of Snow Black Carbon Concentration in Snow Cover in Northeast China from 2001 to 2016 Based on Remote Sensing
}

\author{
Yanjiao Zheng ${ }^{1,2}$, Lijuan Zhang ${ }^{1, *}$, Wenliang Li $^{3}{ }^{\mathbb{C}}$, Fan Zhang ${ }^{1,4}$ and Xinyue Zhong ${ }^{5}$ \\ 1 Information Service in Cold Regions, Harbin Normal University, Harbin 150025, China; \\ zhengyj@nuist.edu.cn (Y.Z.); beibei1923@163.com (F.Z.) \\ 2 Collaborative Innovation Center on Forecast and Evaluation of Meteorological Disasters, Nanjing University \\ of Information Science and Technology, Nanjing 210044, China \\ 3 Department of Geography, Environment and Sustainability, The University of North Carolina at Greensboro, \\ Greensboro, NC 27412, USA; w_li3@uncg.edu \\ 4 College of Tourism Management, Sanya University, Sanya 572000, China \\ 5 Key Laboratory of Remote Sensing of Gansu Province, Northwest Institute of Eco-Environment and \\ Resources, Chinese Academy of Sciences (CAS), Lanzhou 730000, China; xyzhong@lzb.ac.cn \\ * Correspondence: zlj19650205@163.com
}

check for updates

Citation: Zheng, Y.; Zhang, L.; Li, W.; Zhang, F.; Zhong, X. SpatialTemporal Variation of Snow Black Carbon Concentration in Snow Cover in Northeast China from 2001 to 2016 Based on Remote Sensing. Sustainability 2022, 14, 959. https:// doi.org/10.3390/su14020959

Academic Editors: Xiaodong Yan, Jia Yang, Shaofei Jin and Luigi Aldieri

Received: 23 September 2021

Accepted: 10 January 2022

Published: 15 January 2022

Publisher's Note: MDPI stays neutral with regard to jurisdictional claims in published maps and institutional affiliations.

Copyright: (C) 2022 by the authors. Licensee MDPI, Basel, Switzerland. This article is an open access article distributed under the terms and conditions of the Creative Commons Attribution (CC BY) license (https:// creativecommons.org/licenses/by/ $4.0 /)$.

\begin{abstract}
The amount of black carbon (BC) on snow surface can significantly reduce snow surface albedo in the visible-light range and change the surface radiative forcing effect. Therefore, it is key to study regional and global climate changes to understand the BC concentration on snow. In this study, we simulated the $\mathrm{BC}$ concentration on the surface snow of northeast China using an asymptotic radiative transfer model. From 2001 to 2016, the BC concentration showed no significant increase, with an average increase of $82.104 \mathrm{ng} / \mathrm{g}$ compared with that in the early 21st century. The concentration of BC in December was the largest (1344.588 ng/g) and decreased in January and February (1248.619 ng/g and $983.635 \mathrm{ng} / \mathrm{g}$, respectively). The high black carbon content centers were concentrated in the eastern and central regions with dense populations and concentrated industries, with a concentration above $1200 \mathrm{ng} / \mathrm{g}$, while the BC concentration in the southwest region with less human activities was the lowest (below $850 \mathrm{ng} / \mathrm{g}$ ), which indicates that human activities played an important role in snow BC pollution. Notably, Heilongiang province has the highest concentration, which may be related to its atmospheric stability in winter. These findings suggest that the BC pollution in northeast China has been aggravated from 2001 to 2016. It is estimated that the snow surface albedo will decrease by $16.448 \%$ due to the BC pollution of snow in northeast China. The problem of radiative forcing caused by black carbon to snow reflectivity cannot be ignored.
\end{abstract}

Keywords: snow cover; black carbon concentration; radiative forcing; northeast China

\section{Introduction}

Snow cover is widely distributed on land surfaces, with a high albedo, strong radiation, and high insulation, which directly affects the land surface temperature, air temperature, surface albedo, soil moisture, and then affects the radiation balance of the earth-atmosphere system. Thus, snow cover is an important factor in the climate system [1]. The surface albedo of pure fresh snow is very high, generally between $60 \%$ and $95 \%$ [2]. When black carbon (BC) aerosols deposit into the surface snow through dry and wet deposition, even a trace of BC will greatly reduce the albedo of the snow surface, thereby increasing the absorption of solar radiation on the snow surface [3]. Its heating effect will accelerate snow melting and reduce the snow retention time and area [4,5], which, in turn, leads to regional climate change and even affects global climate change [3,6-8]. The fifth report of the IPCC indicates that the global average surface temperature has increased by approximately $0.85{ }^{\circ} \mathrm{C}$ in the past 100 years, and the annual average surface temperature has shown 
an increasing trend in most regions of the world, especially in winter and spring in the mid-high latitudes of the northern hemisphere [9]. In October 2018, the IPCC issued a special report on global warming of $1.5^{\circ} \mathrm{C}$ [10]. However, studies have confirmed that the spatial variation of global temperature is the fastest at high latitudes [11-13]. The impact of human activities on global climate change can be attributed to two factors: (1) change in the chemical composition of the Earth's atmosphere through greenhouse gas emissions, and the "umbrella effect" caused by the excessive increase of aerosols, such as sulfates, and (2) land use and land-cover change (LUCC) $[14,15]$. Previous studies have shown that on a regional or smaller scale, the impact of LUCC on climate is even greater than the contribution of greenhouse gases due to changes in surface energy [16,17]. The most critical surface parameter of LUCC affecting regional climate is to change the surface reflectance; pure fresh snow has a high surface albedo, which is a key climate parameter that significantly affects surface energy balance in the Earth system [18], however, when BC aerosols enter the surface snow and ice through dry and wet deposition, even a small amount of BCwill greatly reduce the albedo of the snow surface, thus increasing the absorption of solar radiation on the snow surface [19], and its heating effect will accelerate snow melting and reduce the snow retention time and area [20], which leads to regional climate change and even affects global climate change [21]. Therefore, as the main emission material of human activities, BC has greatly changed the surface reflectance and has become an important pollutant that changes regional and even global climate. To assess the impact of BC on climate change, it is most important to clarify the concentration of BC on regional snow, and then accurately evaluate its impact on snow and ice albedo and its radiation forcing effect [22].

Owing to the influence of the local environment, human activities, source emissions, and atmospheric circulation, the distribution of BC aerosols in the global snow concentration have strong regional and spatial differences [22,23]. The study of BC concentration in ice and snow began in the 1980s in the South and North Poles [24-26], and then gradually expanded to the middle and low latitudes, achieving numerous results [27-31]. Published data show that BC concentrations in glaciers, ice sheets, and snow cover range from 0.015 to more than $1000 \mathrm{ng} / \mathrm{g}$ globally. Low BC values, which can be pronounced, have been found in Antarctica; while high values, due to $\mathrm{BC}$ emissions and transport, have been observed in mid-latitude snow and ice (Alps, North America, and the Tibetan Plateau) [32]. Doherty et al. [33] indicated that the BC concentration in the snow in the Arctic ranges from a few $\mathrm{ng} / \mathrm{g}$ to dozens of $\mathrm{ng} / \mathrm{g}$, and is about $5 \mathrm{ng} / \mathrm{g}$ in the Arctic; 21-34 $\mathrm{ng} / \mathrm{g}$ in western and eastern Russia; The BC concentration in the snow cover in high-latitude regions are all low, such as Scandinavia, Svalbard, and Fram Strait are $88 \mathrm{ng} / \mathrm{g}, 7-42 \mathrm{ng} / \mathrm{g}$, and $9 \mathrm{ng} / \mathrm{g}$, respectively [34]. The concentration of $\mathrm{BC}$ in snow in most parts of North America ranges from 10 to tens of $\mathrm{ng} / \mathrm{g}$. In central and western North America, the concentration of BC ranges from 5 to $111 \mathrm{ng} / \mathrm{g}$ and has a strong latitude zonality. But up to now, the study of BCconcentration in snow is mainly based on laboratory testing methods based on field sampling samples. The biggest advantage of this method is that the results are more accurate, but it requires a lot of manpower, material resources, and the sampling points are obtained. The quantity is limited, and it is difficult to effectively reflect the distribution characteristics of snow BCconcentration in large-scale areas. Compared with a laboratory test, remote-sensing technology has the advantages of wide coverage and high resolution, it is not limited by climate and geographical conditions, and it objectively and truly reflects the information of land features [35], which has been applied more and more in recent years. Some scholars have proposed a method for simulating the BCcontent in snow with a model based on remote sensing data. For example, Flanner et al. [36] used the SNICAR model to simulate the global average snow surface BCconcentration in 1998 and 2001; M. Namazi et al. [37] used the CanAM4.2 model to simulate the BCcontent of snow in the northern hemisphere. The results of the two studies both show that the BCcontent in the snow in northeast China is the highest in the world, but they only revealed the black carbon content in the snow in the northeast in a certain year or two. Huang et al. [38] collected 
29 snow samples in northeast China from January to February of 2010 and January of 2014. The results of two field snow samples showed that the BC concentration in snow cover in northeast China was 40-1600 ng/g and 50-3700 ng/g, respectively. Negi and Kokhanovsky $[39,40]$ developed the ART model based on the SNICAR model, and realized the inversion of snow particle size and albedo. Wei [41] used the ATR model to invert the BC concentration of snow cover in China from 2000 to 2018; It can be seen that the ART theory has a wide range of applications for snow cover research. It can not only be used to retrieve albedo, but also to retrieve snow particle size and pollutant content [42]. Northeast China is the second largest stable snowpack area in China, and it is also an important heavy industrial base in China. Coal, petroleum, and biomass fuels are the main energy sources consumed and the combustion mode is backward. BC aerosols enter the snow through a dry and wet deposition. Based on the asymptotic radiative transfer (ART) model and remote sensing image data, this study simulates the snow carbon concentration in northeast China from 2001 to 2016 and analyzes its spatiotemporal variation characteristics, which provides a basis for studying global snow carbon concentration and its radiative forcing.

\section{Materials and Methods}

\subsection{Study Area}

The study area is located in the northeast of China, between $37^{\circ}-53^{\circ} \mathrm{N}$ and $115^{\circ}-135^{\circ} \mathrm{E}$, which includes Heilongjiang province, Jilin province, and Liaoning province (Figure 1). This area is the region with the widest range of stable snow cover and the largest average snow depth. The snow cover period here ranges from south to north for 30 to 190 days [43], and the annual cumulative snow depth is $498 \mathrm{~cm}$ [44]. It is distinguished from other snow areas by its large annual average snow reserves and the most obvious inter-annual variability [45]. Simultaneously, the northeast region is a famous heavy industry base of China, and its energy consumption is based on fossil fuels, such as coal and petroleum. In the vast rural areas it still relies on biofuels and its combustion methods are relatively backward. In addition, the use of motor vehicles in urban areas continues to increase. Therefore, BC aerosols are an important group of atmospheric aerosols in northeast China.

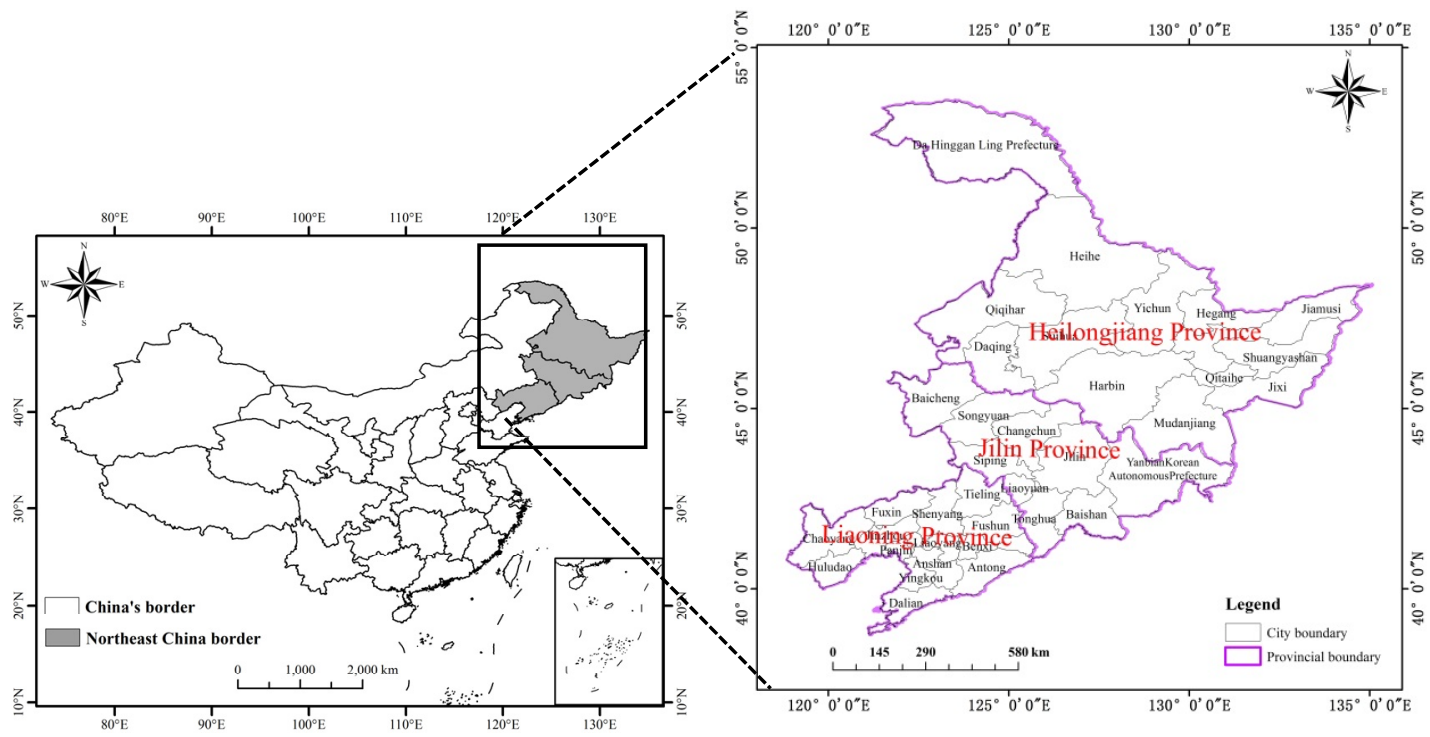

(a)

(b)

Figure 1. Location of study areas. (a) study area in northeast China; (b) three provinces comprising study area (Heilongjiang, Jilin, and Liaoning) ranging in latitude from $37^{\circ} \mathrm{N}$ to $53^{\circ} \mathrm{N}$ and in longitude from $115^{\circ} \mathrm{E}$ to $135^{\circ} \mathrm{E}$. 


\subsection{Data Sets}

\subsubsection{Remote Sensing Data}

The visible reflectance, near-infrared reflectance, solar zenith angle, observational zenith angle, and relative azimuth angle were the main parameters driving the ART model. The above parameters were obtained from the MOD09GA (V6) dataset, which was registered and downloaded from the U.S. National Aeronautics and Space Administration (NASA) data website (https:/ / modis.gsfc.nasa.gov/) (accessed on 28 February 2019). The track numbers were h25v03, h26v03, h26v04, h27v04, and h27v05. The timescale was from January 2001 to December 2016. The data format is HDF. The dataset has been corrected by atmospheric bidirectional reflection and solar altitude angle.

The ground reflectance in the visible-light band is the MOD09GA (V6) dataset in band 2 and that in the near-infrared band is the MOD09GA (V6) dataset in band 3. The spatial resolution of the ground reflectance data in the two bands is $500 \mathrm{~m}$. The solar zenith angle and observation zenith angle are calculated using the corresponding solar zenith angle and observation zenith angle in the MOD09GA (V6) dataset, and the relative azimuth is calculated by using the solar azimuth angle and observation azimuth in the data set. The spatial resolution of the four angles is $1000 \mathrm{~m}$. To match the reflectance data with the angle data in spatial scale, it is necessary to resample the angle data of $1000 \mathrm{~m}$ to $500 \mathrm{~m}$. The data pre-processing process of MOD09GA (V6) includes data-format conversion, resampling, re-projection, splicing, and clipping.

To study the influencing factors of the distribution and variation trend of snow BC concentration in northeast China, the spatial distribution data of China's elevation (DEM) released by the resource and environment data cloud official website (http:/ / www.resdc.cn/ data.aspx?DATAID=284) (accessed on 10 May 2019), the average wind-speed data released by the scientific data center in cold and arid regions (http:/ / westdc.westgis.ac.cn/data/ 7a35329c-c53f-4267-aa07-e0037d913a21) (accessed on 10 May 2019), and the night light time data of the DMSP satellite (https:/ / ngdc.noaa.gov/eog/dmsp/downloadV4composites. html) (accessed on 12 May 2019) were used to discuss the effects of topographic factors, population density, energy factors, and meteorological conditions on the distribution and variation trend of snow $\mathrm{BC}$ concentration in northeast China.

\subsubsection{Field Data}

To validate the model, twice field samples were taken from January to February 2010 and January 2014, totaling 28 points, including 19 in 2010 and 9 in 2014 (Figure 2). The specific sampling process was the following: clean stainless-steel utensils were used to dig out snow pits and make a vertical profile in one direction. When sampling, according to the order of "left" and "right", two snow samples of $0-5 \mathrm{~cm}$ cover in vertical section were collected and placed in Whirlpak sampling bags, sealed, and put into an incubator to ensure that they remained in a solid-state until the next processing step in the temporary laboratory. In the temporary laboratory, samples of the collected snow were scooped into clean glass beakers with clean stainless-steel containers and quickly melted in a microwave oven. After measuring the volume of the melted samples, the melted snow water was filtered through a $0.4-\mathrm{mm}$ Nuclepore filter by a manual pump immediately to separate $\mathrm{BC}$ and other water-insoluble substances [46], and then an ISSW spectrophotometer was used to analyze the BC and other light-absorbing substances in the filter samples [25,47]. Since the BC concentration was estimated based on the Ångström absorption index of the sample on the filter, the $\mathrm{BC}$ concentration of the sample given was a range, not a definite value [48]. For example, the uncertainty range of the BC concentration of a snow sample in Changchun City in early February 2010 was 250-650 ng/g. 


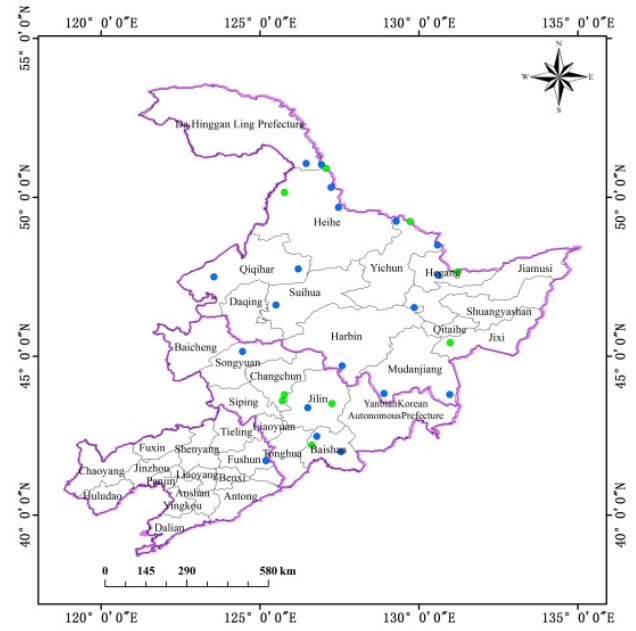

Figure 2. Locations of the 28 sampling sites (blue is the sampling point in 2010 and green is the sampling point in 2014), ranging in latitude from $42^{\circ}$ to $51^{\circ} \mathrm{N}$ and in longitude from $120^{\circ}$ to $131^{\circ} \mathrm{E}$.

\subsection{Methods}

\subsubsection{Snow Recognition Method}

Snow pixel judgment was the basic data for simulating snow BC concentration. In this study, we used the SNOWMAP algorithm to identify snow-covered pixels, which was proposed by Hall et al. [49], and subsequently improved for the production of MODIS snow cover products [50] and has been validated and applied worldwide [51,52].

The core concentration of the SNOWMAP algorithm is normalized difference snow index (NDSI), which uses the spectrum characteristic of the high reflectivity of snow in the visible light band and low reflectance in the near-infrared band to distinguish between clouds and snow. The calculation method is

$$
N D S I=\frac{R(b 4)-R(b 6)}{R(b 4)+R(b 6)}
$$

where, $R(b 4)$ and $R(b 6)$ representrepresents the surface reflectance of band $4(545-565 \mathrm{~nm})$ and band 6 (1628-1652 nm) in the MOD09GA data, respectively.

Hao et al. [53] found that the NDSI threshold was 0.4. The NDSI of water is also greater than 0.4 , so we eliminated the influence of water on snow pixel based on the characteristic that the reflectivity of snow in the second waveband was greater than, or equal to, 0.11 , and the reflectivity of water in this waveband was not greater than 0.11 [50]. Therefore, the discriminant formulas of snow pixels in this study were

$$
\left\{\begin{array}{l}
N D S I \geq 0.4 \\
R(b 2)>0.1
\end{array}\right.
$$

where, $R(b 2)$ represents the surface reflectance of band $2(841-876 \mathrm{~nm})$.

In this paper, the snow pixels identified by the SNOWMAP algorithm were marked as 1 , and the other non-snow pixels were marked as 0 . A snow cover map with a spatial resolution of $500 \mathrm{~m} \times 500 \mathrm{~m}$ was generated.

\subsubsection{ART Model}

The ART model is a simplified radiative transfer model developed by Kokhanovsky et al. $[54,55]$. The basic principle is to regard snow particles as irregular particles, consider the effect of pollutants on the absorption characteristics of the snow surface, the optical characteristics of a single particle are calculated using the principles of geometrical optics, and then the asymptotic analysis solution of the radiative transfer model is obtained using the asymptotic analysis method. The model driving parameters mainly include visible- 
light reflectance, near-infrared reflectance, solar zenith angle, viewing zenith angle, and relative azimuth angle. Snow characteristics, such as the grain effective size $\left(\alpha_{e f}\right)$ and BC concentration $(c)$, can be estimated on regional and global scales.

The formula for simulating the $\mathrm{BC}$ concentration of each grid in snow based on the ART model is:

$$
\begin{gathered}
R_{1}=R_{0} \exp \left[-\frac{4 f\left(\mu, \mu_{0}, \varphi\right)}{\sqrt{3(1-g)}} \sqrt{\frac{2}{3} B \alpha_{s, 1} c \alpha_{e f}}\right] \\
R_{2}=R_{0} \exp \left[-\frac{4 f\left(\mu, \mu_{0}, \varphi\right)}{\sqrt{3(1-g)}} \sqrt{\alpha_{i, 2} \beta K \alpha_{e f}+\frac{2}{3} B \alpha_{s, 2} c \alpha_{e f}}\right]
\end{gathered}
$$

There are 15 parameters in the equations (Equation (3) and (4)), and the physical meaning and units are listed in Table 1 . The snow BC concentration in this study is relative snow concentration.

Table 1. Parameters used in ART model.

\begin{tabular}{cll}
\hline Parameter & \multicolumn{1}{c}{ Physical Meaning } & Unit/Value \\
\hline$R_{1}$ & Surface reflectance of band 3 in MODIS dataset & \\
$R_{2}$ & Surface reflectance of band 2 in MODIS dataset & \\
$R_{0}$ & Reflection function of the semi-infinite snow layer & \\
$f\left(\mu, \mu_{0}, \phi\right)$ & Determined by escape function and semi-infinite space sno & \\
$g$ & layer reflectivity function & 0.76 \\
$B$ & Asymmetry parameter & 0.84 \\
$\alpha_{s, i}$ & Constant & $\mathrm{ng} / \mathrm{g}$ \\
$c$ & Absorption coefficient of BC & $\mathrm{mm}$ \\
$\alpha_{e f}$ & Relative BC concentration & \\
$\alpha_{i, 2}$ & Snow grain size & 0.47 \\
$\beta$ & Absorption coefficient of ice & 2.63 \\
$K$ & Probability of photon absorption & degree \\
$\vartheta_{0}$ & Constant & degree \\
$\vartheta$ & Solar zenith angle & degree \\
$\varphi$ & Viewing zenith angle &
\end{tabular}

$R_{1}, R_{2}, \vartheta_{0}$, and $\vartheta$ in equations (Equations (3) and (4)) can be downloaded from the MODIS data. Other parameters can be obtained using the following equations.

1. Reflection function of the semi-infinite snow layer $R_{\mathbf{0}}$

$R_{0}$ was calculated by the following equation (Equation (2)) [56,57]

$$
R_{0}\left(\mu, \mu_{0}, \varphi\right)=\frac{A+B\left(\mu+\mu_{0}\right)+C \mu \mu_{0}+P(\theta)}{4\left(\mu+\mu_{0}\right)}
$$

\begin{tabular}{|c|c|c|c|c|c|}
\hline Parameter & Mean & Value & Parameter & Mean & Value \\
\hline A & constant & 1.247 & $\mu$ & $\begin{array}{l}\text { The cosine of viewing zenith } \\
\text { angle }\end{array}$ & {$[-]$} \\
\hline$B$ & constant & 1.186 & $\mu_{0}$ & The cosine of solar zenith angle & {$[-]$} \\
\hline C & constant & 5.157 & $P(\theta)$ & The phase function & {$[-]$} \\
\hline
\end{tabular}

The parameters in Equation (5) are listed in Table 2.

Table 2. Parameters needed to calculate $R_{0}$. 
The phase function $P(\theta)$ does not depend on the wavelength, therefore the function $R_{0}$ $\left(\mu, \mu_{0}, \phi\right)$ is the same in the entire spectrum. The phase function $P(\theta)$ is calculated as:

$$
P(\theta)=11.1 \exp (-0.087 \theta)+1.1 \exp (-0.014 \theta)
$$

where, $\theta$ is defined as $\theta=a \cos \left(-\mu \mu_{0}+s s_{0} \cos \varphi\right), s=\sin (\vartheta), s_{0}=\sin \left(\vartheta_{0}\right), \mu_{0}=\cos \left(\vartheta_{0}\right)$, and $\mu=\cos (\vartheta)$.

2. Parameter $f\left(\mu, \mu_{0}, \phi\right)$

$f\left(\mu, \mu_{0}, \phi\right)$ is determined by the escape function and the semi-infinite space snow reflectance function, and its calculation formula is as follows:

$$
f\left(\mu, \mu_{0}, \varphi\right)=\frac{u\left(\mu_{0}\right) u(\mu)}{R_{0}\left(\mu, \mu_{0}, \varphi\right)}
$$

where, $u\left(\mu_{0}\right)$ is called the escape function, which is solved according to the following empirical formulas:

$$
u\left(\mu_{0}\right)=\frac{3}{7}\left(1+2 \mu_{0}\right), u(\mu)=\frac{3}{7}(1+2 \mu)
$$

3. Absorption coefficient of ice crystal and BC

In the visible light band (channel 1), the absorption of light by the snow layer is mainly caused by pollutants (mainly BC); in the near-infrared band (channel 2), the absorption of light by the snow layer is mainly caused by ice crystals and BC.

The formula of the absorption coefficient of $\mathrm{BC}$ is

$$
\alpha_{s, i}=4 \prod \chi_{s}(\lambda) / \lambda_{i}
$$

where, $i=1,2$, indicating the first and second channels. Since the refractive index of $\mathrm{BC}$ is independent of wavelength, $\chi_{s}(\lambda)$ is a constant of 0.46 . $\lambda$ is the wavelength; that is, $\lambda_{1}=$ $460 \mathrm{~nm}$ and $\lambda_{2}=865 \mathrm{~nm}$.

The expression of the light absorption coefficient of ice crystals is

$$
\alpha_{i c e, 2}=4 \prod \chi_{i c e}(\lambda) / \lambda
$$

where, $\alpha_{i c e, 2}$ is the ice absorption coefficient at the wavelength $\lambda_{2} ; \chi_{i c e}(\lambda)$ is the imaginary part of the refractive index of ice, which is a function of wavelength. Here, we use $\chi_{\text {ice }}(\lambda)=2.5 \times 10^{-9}$.

4. Relative azimuth angle $\phi$

$\phi$ is calculated with Equation (11):

$$
\varphi=s a a-v a a
$$

where saa is the solar azimuth angle and vaa is the viewing azimuth angle.

Entering all the above parameters into the ART model, we simulated the BC concentration of each snow pixel with a spatial resolution of $500 \times 500 \mathrm{~m}$.

Based on the above data and formula, we analyzed the BC concentration of snow cover in northeast China, and the research framework is shown as follows (Figure 3): 


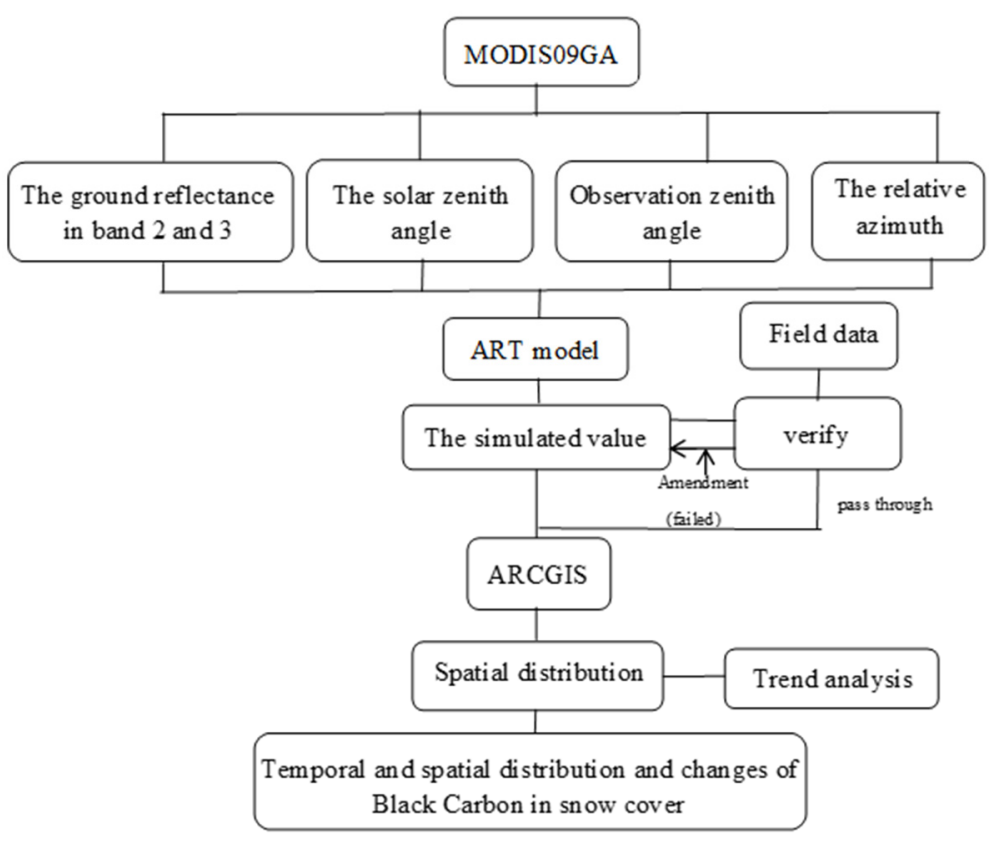

Figure 3. The framework of the study.

\section{Results}

\subsection{Model Verification}

We verified the accuracy of the simulated values by comparing the simulated snow BC concentration with the measured values. Since the measured value was an uncertain range, as long as the simulated value was distributed within the range of the measured value we could consider the simulation result credible. We also used the literature comparison method to verify the simulated value. The field sampling measured datum were used to verify the simulation values of the same period (Figure 4). There are significant disagreements in the measured and modeled snow BC concentrations at individual sites, but over the region as a whole there is no apparent systematic bias in the modeled vs. measured concentrations. Zhao et al. [58] simulated the BC concentration of snow cover in northeast China in 2010, and the simulated value was above $1000 \mathrm{ng} / \mathrm{g}$, similar to the results of this study (1197.468 ng/g). For areas north of $48^{\circ} \mathrm{N}$, the simulated value was higher than the measured value. However, Flanner et al. [36] simulated the snow BC content in the high latitudes of northeast China, and the simulation result was above $1000 \mathrm{ng} / \mathrm{g}$, which is similar to the simulation result of this study. Based on the above comparison, the ART model has a high ability to simulate the BC concentration of snow cover in northeast China, and the simulation results are credible.

\subsection{Annual BC Concentration}

\subsubsection{Temporal Variation}

From 2001 to 2016, the average annual BC concentration of snow cover in northeast China was between 1098.927 and $1257.300 \mathrm{ng} / \mathrm{g}$, with an average value of $1197.468 \mathrm{ng} / \mathrm{g}$. The maximum value appeared in 2016 and the minimum value appeared in 2002 (Figure 5). No significant $(p>0.05)$ increase in BC concentration was observed from 2001 to 2016, with an annual growth rate of $5.137 \mathrm{ng} / \mathrm{g}$. 


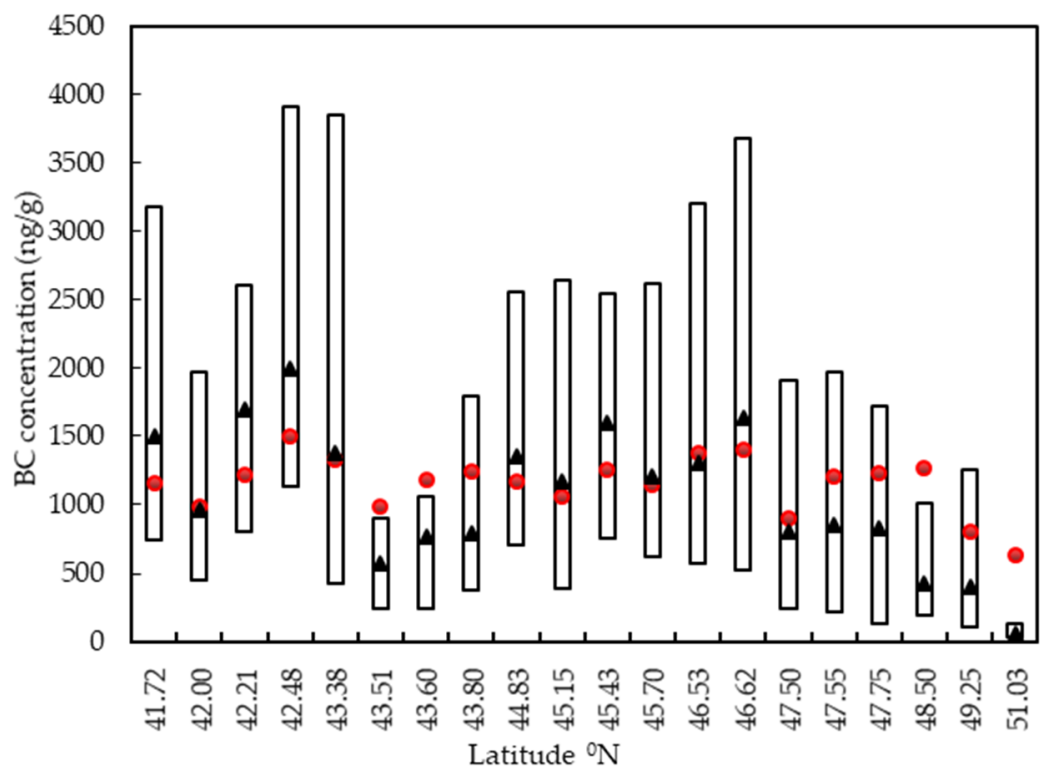

Figure 4. BC concentrations in the top snow layer from the campaign observations (black) and the corresponding ART simulations (red). The column plot of observations shows the minimum and maximum possible values from estimates; the triangle within the column shows the average of observations; and the circle within the column shows the model results.

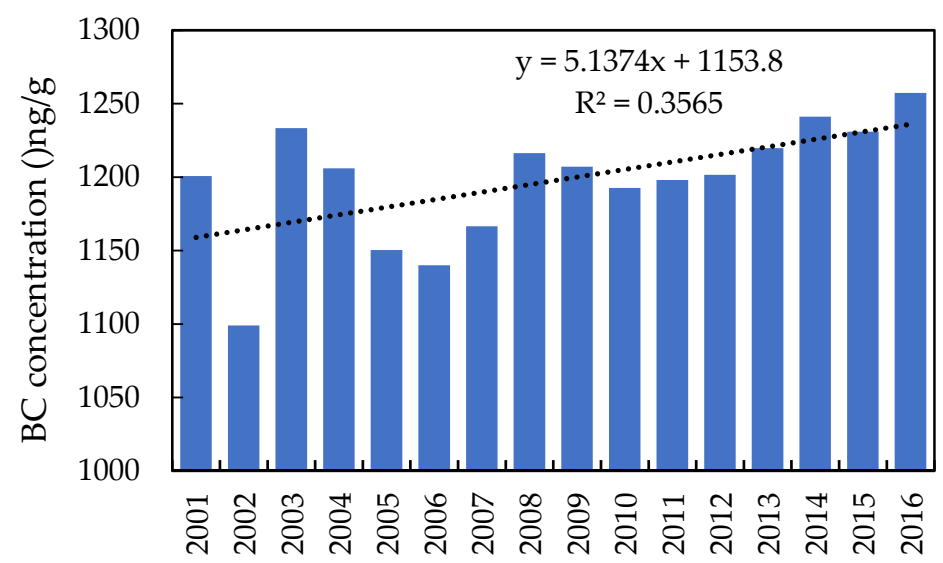

Figure 5. Average annual variability of BC concentration on snow cover in northeast China from 2001 to 2016 .

\subsubsection{Spatial Distribution and Variation}

Figure 6 shows the spatial distribution of the average $\mathrm{BC}$ concentration over northeastern China during 2001 to 2016. There was generally a strong spatial difference in BC concentration that varied considerably over the 310-1561 ng/g range in the study area. Generally, there were two high-value $(>1200 \mathrm{ng} / \mathrm{g})$ regions of BC concentration in northeast China, both of which were located in Heilongjiang province. One is an industrial corridor composing Harbin, Daqing, Qiqihar, Suihua, and Heihe; and the other is a coal-forest industrial area composing Hegang, Jiamusi, and Shuangyashan. Conversely, the average $\mathrm{BC}$ concentration values were largely $<850 \mathrm{ng} / \mathrm{g}$ in the mountainous areas of the study area, where human activity is minimal. 


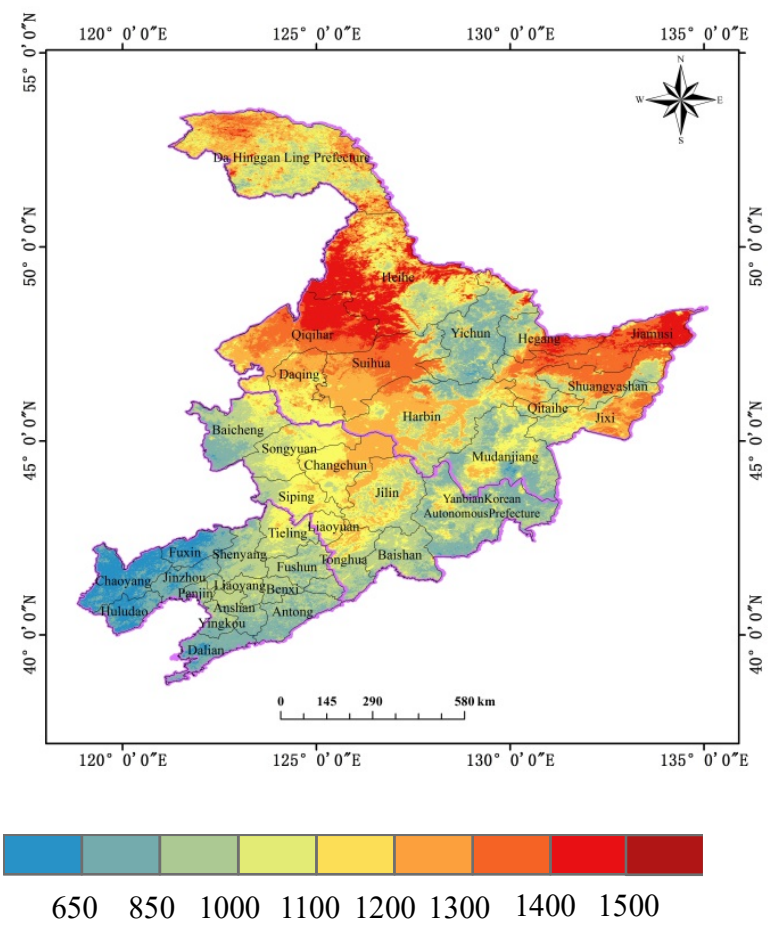

Figure 6. Spatial distributions of the averaged BC concentration over the study area during December to February 2001-2016.

From 2001 to 2016, the BC concentration in $81.805 \%$ of the study area showed an increasing trend (Figure 7). Approximately $6.975 \%$ of the study area showed a significant $(p<0.05)$ increase, which was mainly distributed in the northeast of the Daxinganling region, east of Heihe, north of Qiqihar, northeast of Harbin, north of Suihua, and southeast of Shuangyashan. In contrast, only $18.195 \%$ of the study area showed an insignificant $(p>0.05)$ decrease in BC concentration, which was mainly distributed in the eastern part of Heilongjiang Province and the central and eastern parts of Liaoning Province. Notably, by combining Figures 5 and 6, we found that the heavy snow BC polluted areas centered on the southern part of the Heihe had significantly worsened pollution. In addition, areas where snow cover was less polluted by BC, such as the Xiaoxing' an Mountains, Changbai Mountains, and southern Liaoning, were also becoming more polluted. These results indicate that the $\mathrm{BC}$ pollution degree of snow cover in northeast China increased overall from 2001 to 2016, especially in heavily polluted areas.

\subsection{Monthly Snow BC Concentration}

\subsubsection{Temporal Variation}

The average BC concentration was the highest in December $(1344.588 \mathrm{ng} / \mathrm{g})$, and it was gradually decreased in January (1248.619 ng) and February $(983.635 \mathrm{ng} / \mathrm{g})$, which was related to the cleaning effect of snowfall on the air. The BC concentration in December and January showed an increasing trend from 2001 to 2016, with annual increases of $7.087 \mathrm{ng} / \mathrm{g}$ and $6.556 \mathrm{ng} / \mathrm{g}$, respectively (Figure 8); while in February, it showed a decreasing trend, with an annual reduction of $0.079 \mathrm{ng} / \mathrm{g}$. The coefficients of variation of BC concentration from December to February were 5.601, 8.392, and 8.594, respectively, indicating that the inter-annual distribution of BC concentration in each month was relatively stable. 


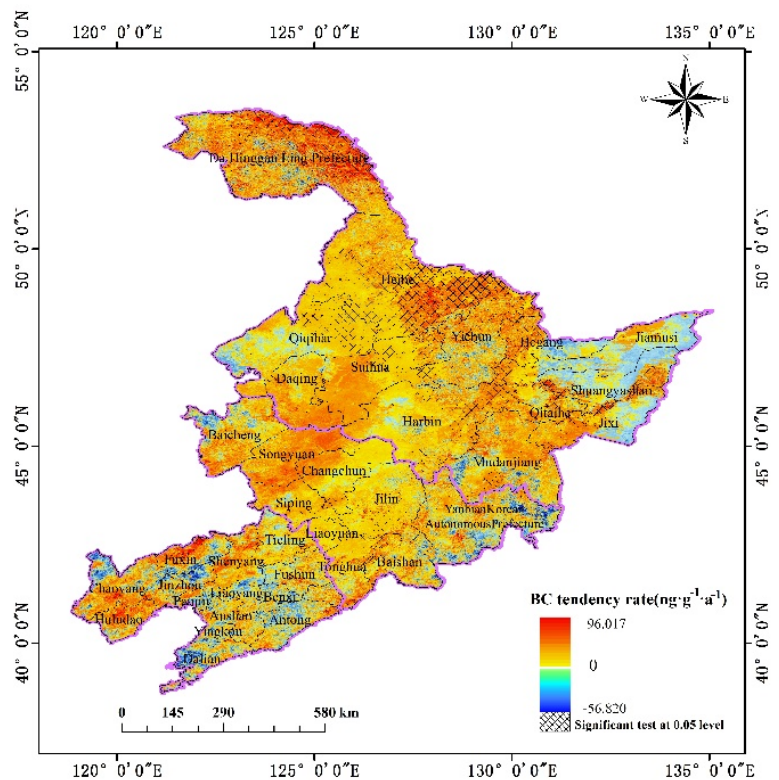

Figure 7. Trends of BC concentration in the top snow layer in northeast China from 2001 to 2016.

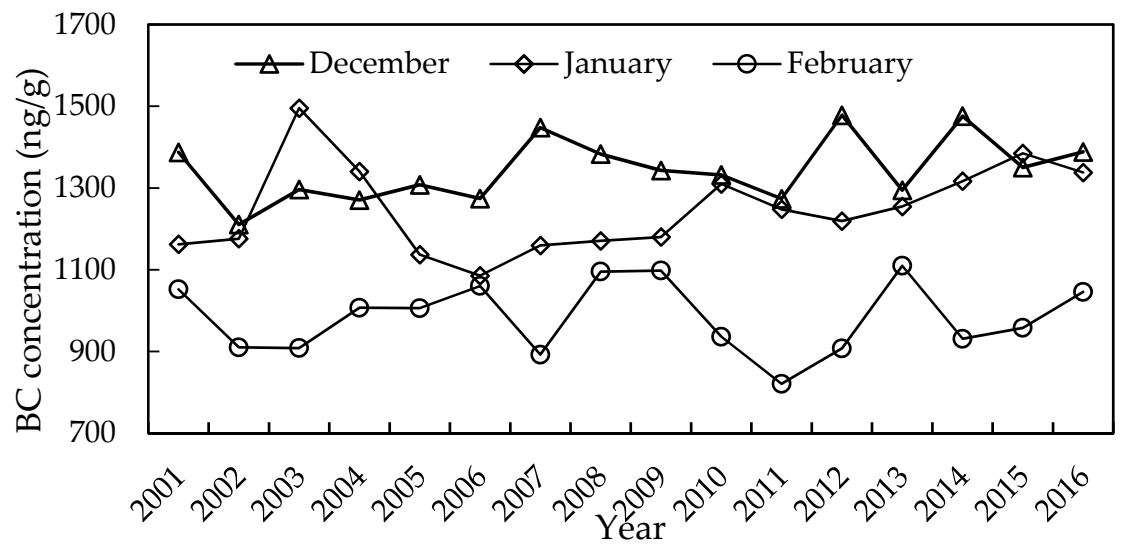

Figure 8. Average annual variability of BC concentration on snow cover in December, January, and February from 2001 to 2016.

\subsubsection{Spatial Distribution and Variation}

Figure 9 shows the spatial distribution of the average BC concentration in December, January, and February over northeastern China during 2001 to 2016. There was generally a strong spatial difference in $\mathrm{BC}$ concentration monthly that showed higher values in the north than in the south. In December, the BC content was greater than $850 \mathrm{ng} / \mathrm{g}$, and there were three high-value centers ( $>1400 \mathrm{ng} / \mathrm{g})$ in the spatial distribution, located in the Daxinganling region, northern Qiqihar and southern Heihe, and Hegang and Jiamusi regions. In January, the high-value center range shrank sharply, especially in northern Qiqihar and southern Heihe. By February, the BC content in the study area was drastically reduced, falling below $1200 \mathrm{ng} / \mathrm{g}$. Areas with low BC concentration $(<900 \mathrm{ng} / \mathrm{g})$ were located in Yichun City, Huludao City, Chaoyang City, Fuxin City, and Dalian City. 


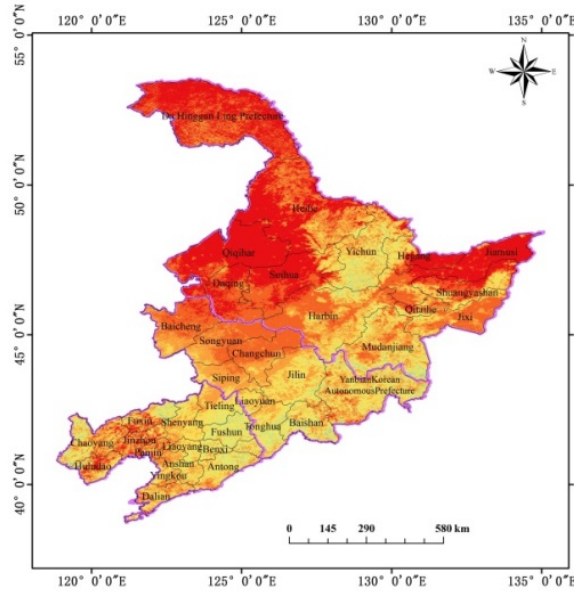

(a)

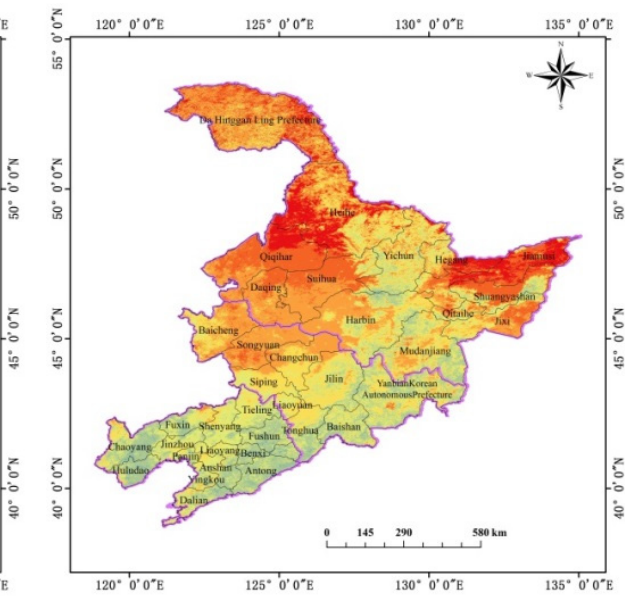

(b)

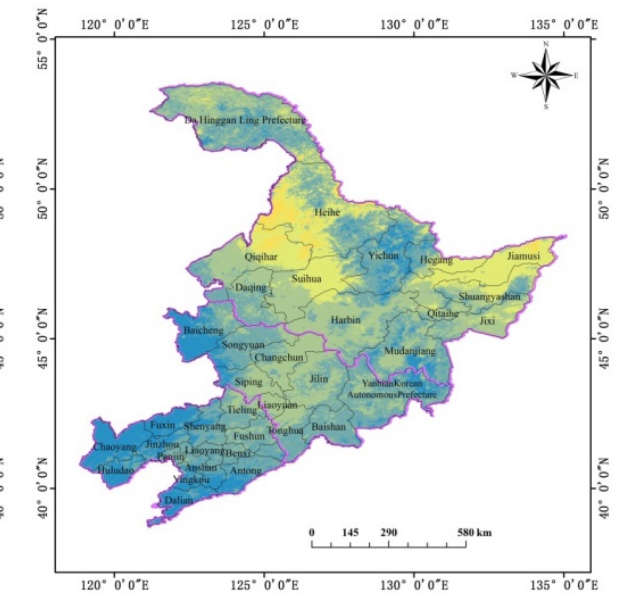

(c)

$\begin{array}{llllllll}650 & 850 & 1000 & 1100 & 1200 & 1300 & 1400 & 1500\end{array}$

Figure 9. Monthly mean value of BC concentration on snow cover in the northeast of China from 2001 to 2016: (a) December, (b) January, and (c) February.

From 2001 to 2016, the increasing trend of BC content in December and January accounted for $82.519 \%$ and $82.789 \%$ of the total area, respectively (Figure 10). Among them, the $\mathrm{BC}$ concentration in central Heilongjiang Province and southern Liaoning increased significantly $(p<0.05)$, accounting for $9.922 \%$ and $10.603 \%$ of the total area, respectively, indicating that $\mathrm{BC}$ concentration in central Heilongjiang Province increased significantly in December and January. On the contrary, the area with a decreasing trend of BC content in February accounted for $60.110 \%$ of study area, and BC concentration decreased significantly $(p<0.05)$ in the southern Greater Xing'an Mountains and northern Heihe, accounting for $2.015 \%$ of the entire northeast area.

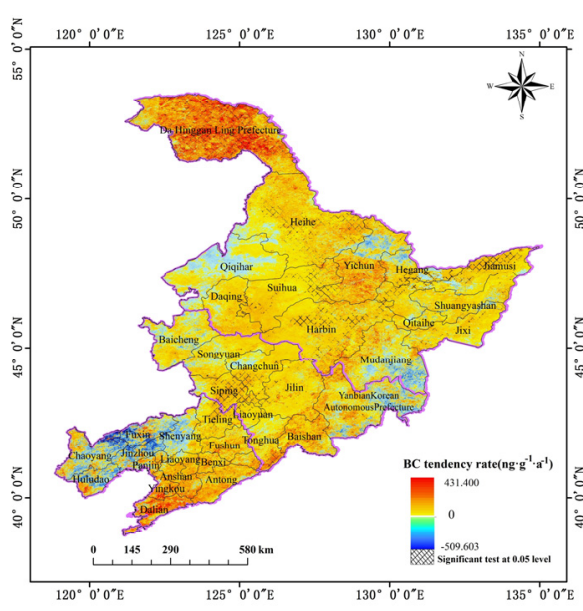

(a)

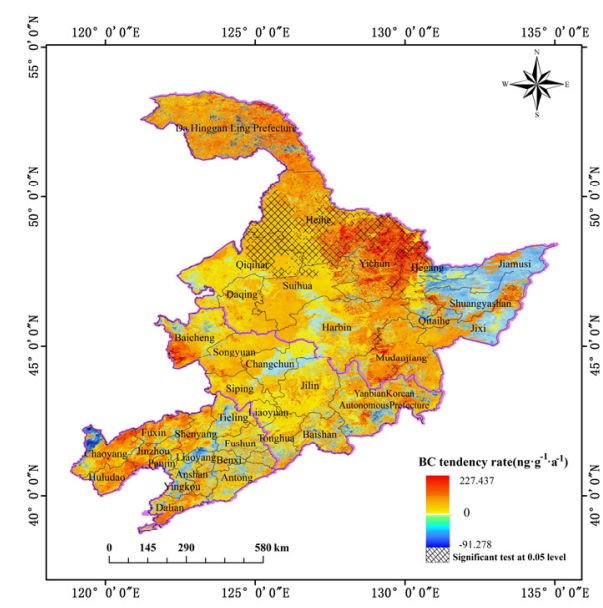

(b)

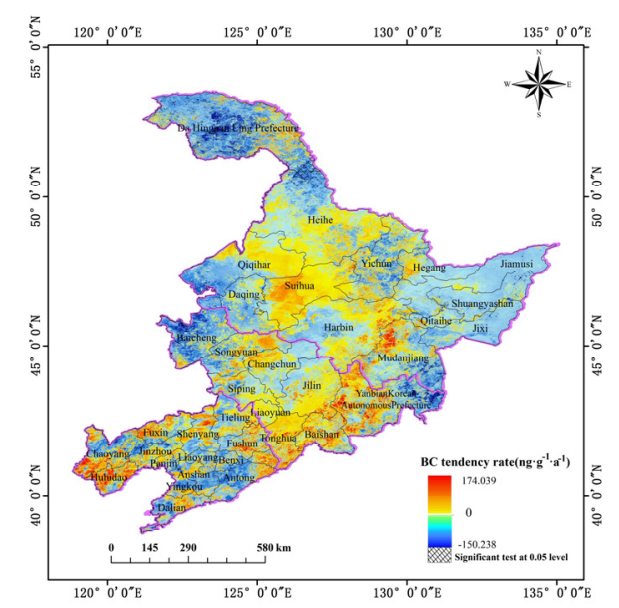

(c)

Figure 10. Monthly average snow BC concentration tendency rate of northeast China from 2001 to 2016: (a) December, (b) January, and (c) February.

\subsection{Influencing Factors}

\subsubsection{Terrain}

The BC on the snow is mainly the dry deposition of BC aerosols in the atmosphere, therefore the difference in the spatial distribution of $\mathrm{BC}$ concentration on the snow is 
mainly determined by the difference in the spatial distribution of the $\mathrm{BC}$ aerosols in the atmosphere. Lv et al. [59] found that elevation is the most important factor contributing to the concentration distribution of BC aerosols, followed by population density, and heavy industry scale. Owing to the sparse population of high-altitude areas, the lack of large-scale heavy industrial production, and the high coverage of surface vegetation in these areas, the concentration of BC aerosols is low. The northeast of China is surrounded by mountains on three sides (Figure 11), while the central and eastern regions are plains and terraces. Therefore, the concentration of BC aerosol in the central region is relatively high. This is consistent with the conclusion that the $\mathrm{BC}$ content of snow in the central plain area is higher than that in the surrounding mountainous areas. It shows that geomorphology types are one of the factors that affect the BC concentration in snow.

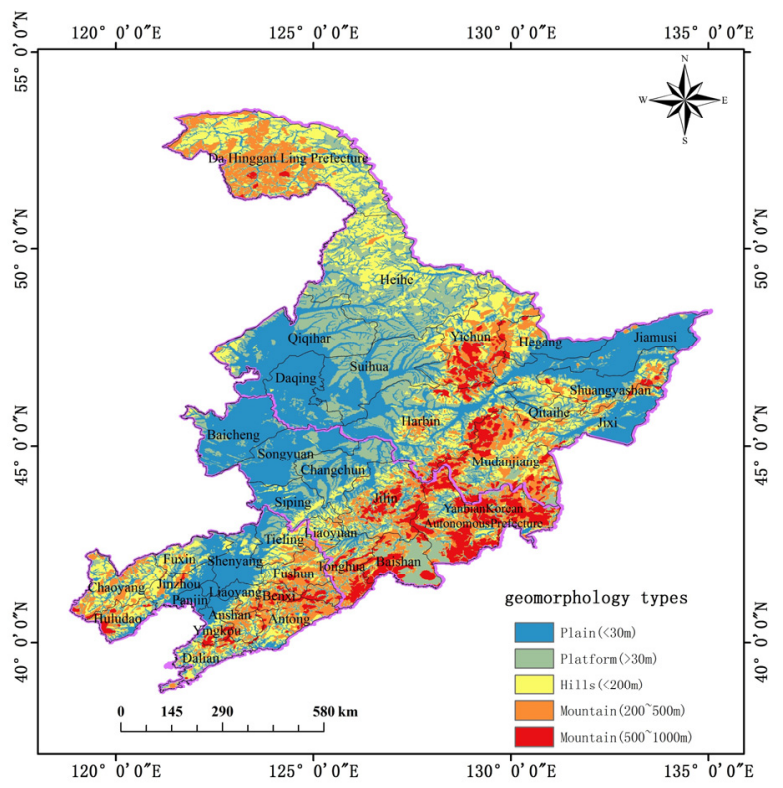

Figure 11. Geomorphology types of northeast China.

\subsubsection{Energy Consumption}

$\mathrm{BC}$ aerosols in the atmosphere mainly come from the incomplete combustion of fossil fuels and biomass fuels. Studies showed that population density and the scale of heavy industry are also important factors affecting the distribution of BC aerosol concentration [59]. The value of the night light time index can reflect the amount of power consumption, representing information such as city size, population density, and energy use [60,61]. Therefore, this study selects the spatial distribution of nighttime light index data in northeast China in 2001 and 2013 (Figure 12), which represents information such as population density and energy usage. The high values of night light hours in 2001 and 2013 were located in Shenyang, Changchun, Harbin, and Daqing, showing a clear zonal distribution. The Songnen Plain in the west and the Sanjiang Plain in the east are also areas with relatively high nighttime light index, suggesting that they are the areas with large cities, concentrated industrial production, and high population density in the three northeastern provinces. Comparing the spatial distribution of snow BC in northeast China in 2001 and 2013, it can be seen that the high value area of the nighttime light index in northeast China in 2001 and 2013 is basically consistent with the high value area of snow BC concentration. Comparing the spatial changes of the nighttime light index in 2013 and 2001, the areas with light index in western, central and eastern Heilongjiang Province have increased significantly. This is the main reason why BC concentration of winter snow in Heilongjiang province became the largest region in northeast China from 2001 to 2016, and BC concentration of winter snow in central and eastern Heilongjiang Province increased significantly. In addition, it can also be seen that the density and scale of cities in the southern part of northeast China 
have increased significantly. Therefore, the concentration of BC in the snow in the southern part of northeast China in 2013 showed an increasing trend in most areas compared with 2001. The above results indicate that population density, city size, and energy consumption are important factors affecting the concentration of $\mathrm{BC}$ in snow.
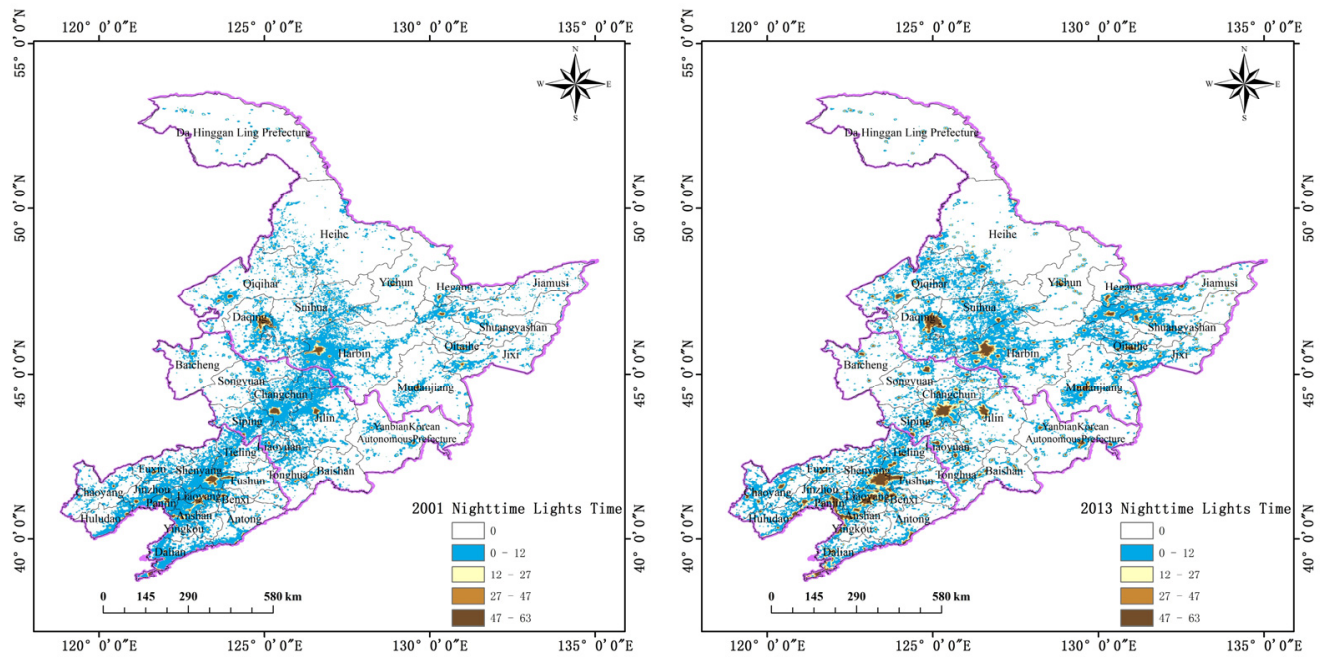

Figure 12. Spatial distributions of Nighttime Lights Time in northeastern China in 2001 and 2013.

\subsubsection{Atmospheric Stability}

The spatial distribution characteristics of BC concentration on snow cover in northeast China are not only affected by terrain and energy consumption, but also related to winter atmospheric stability. When the atmosphere stratification is in a stable state, the poor diffusion ability of the atmosphere makes it difficult for the pollutants to diffuse; otherwise, the pollutants are easy to diffuse [62]. In this study, the average wind speed was used to characterize the stratification stability of the near-surface atmosphere. The lower the wind speed, the more stable the atmospheric layer structure, and the more likely it is to form high-concentration pollution in local areas. Figure 13 shows the average winter wind speed from 2001 to 2016 (December, January, and February the following year). It can be seen from Figure 12 that the winter wind speed was generally low and the atmospheric stratification was relatively stable. The wind speed in the eastern region was relatively high, mainly due to the formation of canyon winds between the Xiaoxing'anling Mountains and Changbai Mountains. In particular, in the central and northern regions of Heilongjiang Province, the wind speed was the lowest, therefore the atmosphere stratification in this area was stable. In addition, the winter temperature was low and the mixed layer was not high, resulting in frequent occurrence of temperature inversions. These climatic conditions hinder the diffusion of BC aerosols. Moreover, these areas were surrounded by mountains on three sides, and the BC aerosols were more difficult to transport outwards and accumulate near the ground. They enter the snow surface through dry deposition, resulting in northern Qiqihar, southern Heihe, and northern Suihua being the high centers of BC in the northeast.

\subsubsection{Land Use Type}

Land use type can not only indicate the coverage of surface vegetation, but also a direct result of the impact of human activities on the surface. Comparing the land use types in northeast China in 2020 with the simulation of the spatial distribution of BC in northeast China from 2001 to 2016 (Figure 14), it can be seen that the areas where cultivated land and cities are consistent with high-value areas of BC in the snow, the correlation coefficient between urban area expansion and BC concentration increase is $0.584(p<0.05)$. It shows that human activities can also affect the concentration of $\mathrm{BC}$ in the snow by changing the land use type. 


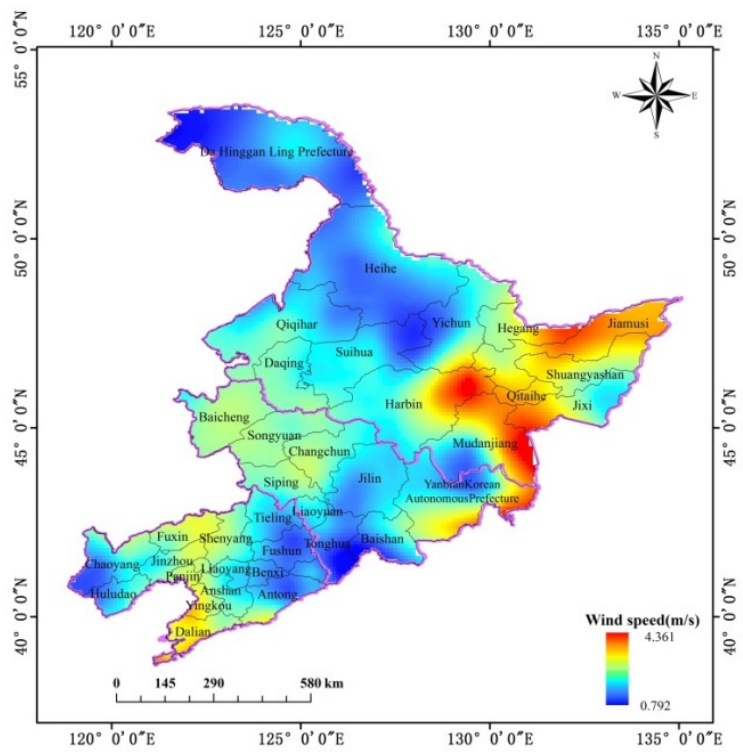

Figure 13. Average winter (December, January, and February the following year) wind speed in northeast China from 2001 to 2016.

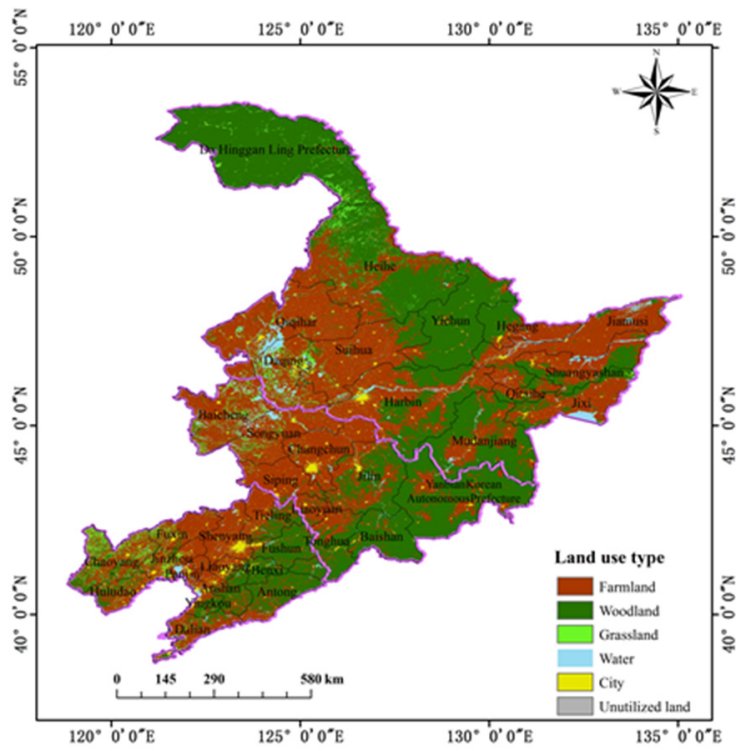

Figure 14. Spatial distributions of land use type in northeastern China in 2020.

In conclusion, the BC content of snow cover in northeast China is affected by both natural and artificial factors. Natural factors are mainly affected by terrain and stable atmosphere stability. Due to sparse population and no large-scale heavy industry production, the concentration level of BC aerosol in high-altitude areas is relatively low. When the atmosphere stratification is in a stable state, the poor diffusion ability of the atmosphere makes it difficult for the pollutants to diffuse, and the $\mathrm{BC}$ concentration increased. Human factors mainly include urban expansion, energy structure change, and land use change, among which urban density, urban size, and population density are important factors affecting the distribution of snow BC concentration. The BC concentration in snow cover is the highest in the region where farmland and city are located, suggesting that human activities affect the spatial distribution of $\mathrm{BC}$ content in snow cover by changing the surface type. 


\section{Discussion}

This study used the ART model combined with remote-sensing data to simulate the BC concentration on snow cover in northeast China. Compared with the existing research results, this study not only analyzed the spatial and temporal distribution of BC concentration on snow cover in northeast China from 2001 to 2016, but also further analyzed the characteristics of snow BC concentration in northeast China during the year and inter-annually, and briefly analyzes its influencing factors.

In this paper, through simulations, a long-term series of snow BC concentrations in a certain area, and the spatial distribution and changes of snow BC concentrations with high spatial resolution year by year were obtained. Compared with previous studies, there are few similar studies, and it is also one of the main contributions of this paper. The research results are of great significance for snow albedo simulation research, improvement of regional climate model simulation accuracy, and snow pollution prevention and control. The results showed that the BC content of snow cover in northeast China did not increase significantly from 2001 to 2016, but increased by $52.299 \mathrm{ng} / \mathrm{g}$ from 2012 to 2016, compared with that from 2001 to 2005 . The $93.25 \%$ of the northeast showed an insignificant trend, and the significant increase areas were mainly distributed in the northeast of the Daxinganling region, the east of Heihe City, the northern edge of Yichun City, and the southeast of Shuangyashan City.

Owing to the influence of local environment, human activities, source emissions, and atmospheric circulation, the global distribution of BC aerosol concentration is highly regional, therefore the $\mathrm{BC}$ concentration on snow is also significantly different in space. The results show that in the inaccessible Antarctic, the average $\mathrm{BC}$ concentration on snow is only $0.2 \mathrm{ng} / \mathrm{g}$ [26], while the BC concentration in the Arctic is higher than that of the Antarctic, with an average of $25 \mathrm{ng} / \mathrm{g}$ [24]. At the same time, the results of studies by Clarke and Noone [24], Warren and Clarke [26], Doherty et al. [25], Grenfell et al. [63,64], and McConnell et al. [65] show that the variation of snow BC concentration in the European Arctic are greater than in the Canadian Arctic and Arctic Oceans, and the reason may be related to the distance to the source of $\mathrm{BC}$ emissions. The snow $\mathrm{BC}$ concentration in the middle and low latitudes of mountainous and urban areas is much higher than that in the Antarctic and Arctic regions. For example, the snow BC concentration in the Alps in December 1992 was 22-302 ng/g [31], and the BC concentration of Olympus in the United States in 2012 was $250 \mathrm{ng} / \mathrm{g}$ [66]. The average BC concentration of glaciers in the Tibetan Plateau and Xinjiang from 2001 to 2004 was 63 ng/g [67]. The ice core in the monsoon climate zone of the Tibetan Plateau shows that BC concentration has increased rapidly since the 1980s, and the glaciers in the southeast of the Tibetan Plateau have accelerated to retreat [68], indicating that anthropogenic BC aerosol emissions in southeast Asia play an increasingly important role in glacial melting on the Tibetan Plateau. Mid-latitude urban areas have the highest snow BC concentration. For example, snow samples from southern New Mexico and northern Texas in the United States from 1982 to 1985 show that the BC concentration in urban areas is three times that of remote rural areas $[28,29]$; the range of snow BC concentration in the city of Detroit from 1984 to 1985 was $17-5700 \mathrm{ng} / \mathrm{g}$ [30]. In 2007-2009, the BC concentration in the surface snow reached $2740 \mathrm{ng} / \mathrm{g}$ in the Sapporo area of Japan [27]. In January and February 2010 and January 2014, the snow BC concentration of northeast China was 40-1600 ng/g and 50-3700 ng/g, respectively. At the same time, it can be seen from the two sampling results that the snow BC concentration in the northeast heavy industrial area is higher than that in the northern border area $[38,48,69]$. The above statements all reflect the impact of human activities on regional snow BC concentration.

Since the strong absorption of light by BC aerosols in the atmosphere was discovered in the 1980s, scientists have subsequently discovered that the albedo of visible light in snow depends largely on the concentration of BC on snow. Warren and Wiscombe [3] believe that trace amounts of light-absorbing substances can significantly reduce the snow surface albedo in the visible light band, but have little effect on the albedo in the nearinfrared band. This study summarized previous measurements of simulated snow BC 
concentrations and corresponding reduced albedo to obtain a simple equation between the BC concentration and its reduced albedo (Figure 15). Using the equation given in Figure 15, the amount of albedo reduction caused by the BC concentration simulated in this study was roughly calculated (Table 3). The estimation results showed that the larger the snow BC concentration, the more the albedo decreases. These results are only theoretical estimates and require field measurements for future verification.

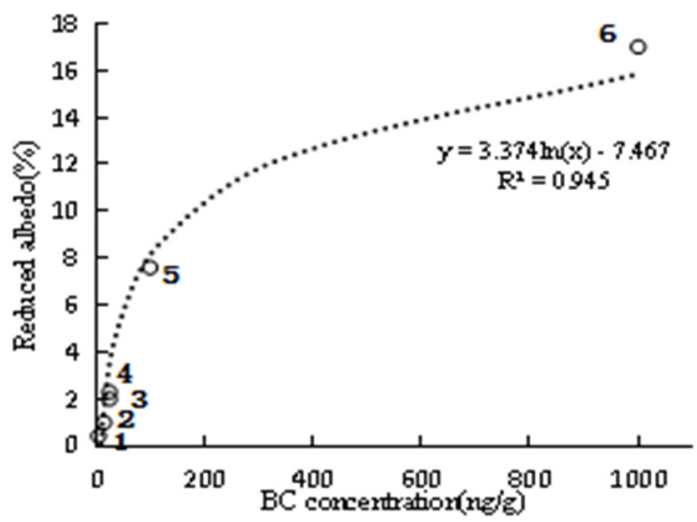

Figure 15. Logarithmic scatter plot for BC concentrations and reduced albedos (hollow circles) in snow and ice based on previous studies, and the simple linear relationship possibly existing between them. The data of the 6 points in the figure are from the literature: 1-Jacobson [8]; 2-Warren [3]; 3-Jacobson [8]; 4-Clarke and Noone [24]; 5-Jacobson [8]; 6-Flanner [7].

Table 3. BC concentration and its reduced albedo in the three northeastern provinces and capital cities.

\begin{tabular}{ccc}
\hline & BC Concentration $\mathbf{( n g} / \mathbf{g})$ & Reduced Albedo $\mathbf{( \% )}$ \\
\hline Annual-mean value & 1197.468 & 16.448 \\
Heilongjiang Province & 1103.617 & 16.172 \\
Jilin Province & 962.440 & 15.711 \\
Liaoning Province & 788.96 & 15.040 \\
Harbin City & 1051.787 & 16.010 \\
Changchun City & 1093.404 & 16.141 \\
Shenyang City & 864.628 & 15.349 \\
\hline
\end{tabular}

In addition to BC, light-absorbing pollutants on snow cover include organic carbon (OC) and mineral dust (MD), accounting for $11.7 \%$ of total light absorption [69]. OC comes from the incomplete combustion of fossil fuels and biomass fuels, which are deposited on the snow surface after dry and wet deposition. MD mainly comes from the arid and semi-arid desert areas of Mongolia. Under the influence of winter monsoon, the dust in the desert area is lifted up and transported to the northeast region and deposited on the surface of the snow there. ART model does not have the ability to detect OC and MD concentration on snow. Therefore, in future research, OC and MD must be taken into account. Based on the optical characteristics of the three substances, BC, OC, and MD, the ART model parameters should be improved to make it more suitable for the characteristics of snow pollution in northeast China.

Compared with the previous research, this study proposed to increase the influence factors of land use type and reached the conclusion that cultivated land and snow BC high value area are highly consistent. But why is the content of $\mathrm{BC}$ in the snow in the area where the cultivated land is located so high? The mechanism needs to be further discussed. Because northeast China is one of the three largest black lands in the world, is there a high BC content in the simulation due to incomplete snow cover in the grid and part of the black lands? This also needs to be further revised through field investigations. In addition, this paper used the lighting index to indirectly analyze the impact of population 
density, energy consumption, and urban expansion on the concentration of $\mathrm{BC}$ in the snow. The relationship between the lighting index and population density, energy consumption, and city size and expansion need further analysis. The research conclusions of this study showed that the BC content of northeast China's snow cover increased by $52.299 \mathrm{ng} / \mathrm{g}$ from 2012 to 2016 compared with 2001 to 2005. In fact, there was a net loss of population in northeast China in the recent five years. Why is the $\mathrm{BC}$ content in snow cover increasing? This also needs to be combined with the actual data for further analysis.

The model only considers the situation that $\mathrm{BC}$ is deposited on the snow surface through dry sedimentation, but it does not consider the situation that $\mathrm{BC}$ particles dissolve in the snow particles. After $\mathrm{BC}$ is deposited in the snow, the snow gradually ages and deforms until the snow melts as time goes by. During this period, the $\mathrm{BC}$ particles migrate with the snow melt water, and their effective particle size and optical properties change. In the future, we can observe the change process of $\mathrm{BC}$ in snow and perform experimental simulation to establish the model mechanism, so as to more accurately simulate its influence on albedo.

\section{Conclusions}

(1) From 2001 to 2016, the average annual BC concentration in northeast China was between 1098.927 and $1257.300 \mathrm{ng} / \mathrm{g}$, with an average value of $1197.468 \mathrm{ng} / \mathrm{g}$. Industrial corridors composed of Harbin, Daqing, Qiqihar, Suihua, and Heihe and coal-forest industrial production areas composed of cities such as Hegang, Jiamusi, and Shuangyashan were high-value centers of snow $\mathrm{BC}$ concentration. The area with increased $\mathrm{BC}$ concentration accounted for $81.805 \%$ of the study area, of which $6.975 \%$ was a significant increase area, mainly distributed in the middle of Heilongjiang Province.

(2) The BC concentration of northeast China was the highest in December (1344.488 ng/g), followed by January and February from 2001 to 2016. From 2001 to 2016, the BC concentration of snow cover in December and January in northeast China showed an increasing trend, while the $\mathrm{BC}$ concentration in February showed a decreasing trend, with no significant increase or decrease trend in each month.

(3) The high vales of BC concentration in Shenyang, Changchun, Harbin, and Daqing are due to large population density and concentrated industrial production. In the central part of Heilongiiang province, due to the stability of the atmospheric stratum and the influence of topographical conditions, the pollutants were not easy to diffuse, causing Heilongjiang province to become the center of high BC concentration. The increase of cultivated land area, urban density and scale, and the expansion of population area are the main reasons for the increase of $\mathrm{BC}$ concentration in snow cover, and also the reasons for the high value of $\mathrm{BC}$ content in snow cover in Heilongjiang Province.

This study simulated the BC concentration of surface snow, analyzed the temporal and spatial distribution and variation characteristics of $\mathrm{BC}$ concentration, and analyzed the influencing factors of $B C$ concentration of surface snow in northeast China from 2001 to 2016. Compared with previous studies, the main contribution of this study is to analyze the distribution characteristics of in snow cover with large scale and high resolution, and to obtain the variation characteristics of BC concentration in snow (2001-2016) in northeast China. The results of this study provide important basic data for simulating the albedo of snow cover in winter in northeast China and analyzing the influence of snow cover on the regional climate. The shortcomings of current studies lie in the need to further improve the spatial resolution of the simulation of snow $\mathrm{BC}$ concentration, refine the analysis of temporal and spatial distribution and variation factors of snow $B C$, and deepen the study of the influence of $\mathrm{BC}$ on snow albedo.

Author Contributions: Y.Z. designed the research framework and drafted the manuscript; L.Z. completed the manuscript and made major revision; W.L. was involved in the design and revision of the manuscript; F.Z. and X.Z. were involved in data acquisition and analysis. All authors have read and agreed to the published version of the manuscript. 
Funding: This research was funded by the National Natural Science Foundation of China under grant number 41771067 and the Key projects of Natural Science Foundation of Heilongiang Province under grant number ZD2020D002.

Institutional Review Board Statement: Not applicable.

Informed Consent Statement: Not applicable.

Data Availability Statement: The data presented in this study are available by request from the corresponding author.

Acknowledgments: We sincerely thank Wang Xin of Lanzhou University for providing snowfield sampling data for this study.

Conflicts of Interest: The authors declare no conflict of interest.

\section{References}

1. Wang, X.; Zhang, Q.; Guo, N.; Cai, D.H. Method for Discrimination Snow in Qilian Mountain Region Based on MODIS Data. Arid Meteorol. 2007, 25, 29-34. (In Chinese)

2. Lei, X.C.; Song, K.S.; Du, J.; Wu, Y.Q.; Wang, Y.D.; Tang, X.G.; Zeng, L.H. Analysis on the spectral reflectance response to snow contaminants in Northeast China. J. Grad. Sch. Acad. Sin. 2011, 28, 611-616. (In Chinese)

3. Warren, S.G.; Wiscombe, W.J. A Model for the Spectral Albedo of Snow. II: Snow Containing Atmospheric Aerosols. J. Atmos. Sci. 1980, 37, 2734-2745. [CrossRef]

4. $\quad$ Painter, T.H.; Barrett, A.P.; Landry, C.C.; Neff, J.C.; Cassidy, M.P.; Lawrence, C.R.; McBride, K.E.; Farmer, G.L. Impact of disturbed desert soils on duration of mountain snow cover. Geophys. Res. Lett. 2007, 34, 237-254. [CrossRef]

5. Ming, J.; Xiao, C.D.; Qin, D.H.; Helene, C. Climate Forcing of Black Carbon in Snow and Ice. Adv. Clim. Chang. Res. 2006, 2, 238-241.

6. $\quad$ Flanner, M.G.; Zender, C.S.; Hess, P.G.; Mahowald, N.M.; Painter, T.H.; Ramanathan, V.; Rasch, P.J. Springtime warming and reduced snow cover from carbonaceous. Atmos. Chem. Phys. 2009, 9, 2481-2497. [CrossRef]

7. Flanner, M.G.; Zender, C.S.; Randerson, J.T.; Rasch, P.J. Present-day climate forcing and response from black carbon in snow. J. Geophys. Res. 2007, 112, D11202. [CrossRef]

8. Jacobson, M.Z. Climate response of fossil fuel and biofuel soot, accounting for soot's feedback to snow and sea ice albedo and emissivity. J. Geophys. Res. Atmos. 2004, 109, D21201. [CrossRef]

9. Allen, S.K.; Plattner, G.-K.; Nauels, A.; Xia, Y.; Stocker, T.F. Climate Change 2013: The Physical Science Basis. An overview of the Working Group 1 contribution to the Fifth Assessment Report of the Intergovernmental Panel on Climate Change (IPCC). In Proceedings of the EGU General Assembly Conference Abstracts, Vienna, Austria, 27 April-1 May 2014.

10. Bongaarts, J. Intergovernmental Panel on Climate Change Special Report on Global Warming of $1.5^{\circ} \mathrm{C}$ Switzerland: IPCC, 2018. Popul. Dev. Rev. 2019, 45, 251-252. [CrossRef]

11. Kim, S.J.; Choi, H.; Kim, B.; Park, S.; Shim, T.; Kim, J. Analysis of recent climate change over the Arctic using ERA-Interim reanalysis data. Chin. J. Polar Res. 2013, 24, 326-338.

12. Screen, J.A.; Deser, C.; Simmonds, I. Local and remote controls on observed Arctic warming. Geophys. Res. Lett. 2012, 39, 10709. [CrossRef]

13. Xu, W.; Li, Q.; Jones, P.; Wang, X.L.; Trewin, B.; Su, Y.; Chen, Z.; Zhai, P.; Wang, J.; Vincent, L. A new integrated and homogenized global monthly land surface air temperature dataset for the period since 1900. Clim. Dyn. 2017, 50, 2513-2536. [CrossRef]

14. Concepts, R. Fourth Assessment Report: Climate Change, 2007 (AR4). PLoS ONE 2014, 6, e16126.

15. Hua, W.; Chen, H.; Xing, L. Review of Land Use and Land Cover Change in China and Associated Climatic Effects. Adv. Earth Sci. 2014, 29, 1025-1036.

16. Sung, J.H.; Eum, H.-I.; Park, J.; Cho, J. Assessment of Climate Change Impacts on Extreme Precipitation Events: Applications of CMIP5 Climate Projections Statistically Downscaled over South Korea. Adv. Meteorol. 2018, 2018, 1-12. [CrossRef]

17. Forestieri, A.; Arnone, E.; Blenkinsop, S.; Candela, A.; Fowler, H.; Noto, L.V. The impact of climate change on extreme precipitation in Sicily, Italy. Hydrol. Process. 2018, 32, 332-348. [CrossRef]

18. He, C.; Liou, K.N.; Takano, Y.; Ling, P.Y.; Qi, Y.; Chen, F. Impact of Grain Shape and Multiple Black Carbon Internal Mixing on Snow Albedo: Parameterization and Radiative Effect Analysis. J. Geophys. Res. Atmos. 2018, 123, 1253-1268. [CrossRef]

19. Skiles, S.M.; Flanner, M.; Cook, J.M.; Dumont, M.; Painter, T.H. Radiative forcing by light-absorbing particles in snow. Nat. Clim. Chang. 2018, 8, 964-971. [CrossRef]

20. Dou, T.F.; Xiao, C.D. An overview of black carbon deposition and its radiative forcing over the Arctic. Adv. Clim. Chang. Res. 2016, 7, 115-122. [CrossRef]

21. Schmale, J.; Flanner, M.; Kang, S.; Sprenger, M.; Zhang, Q.; Guo, J.; Li, Y.; Schwikowski, S.; Farinotti, D. Modulation of snow reflectance and snowmelt from Central Asian glaciers by anthropogenic black carbon. Sci. Rep. 2017, 7, 40501. [CrossRef]

22. Liu, C.M.; Dang, S.Z.; Wang, Z.G.; Wang, S.G. Research Progress of Black Carbon in Snow and Ice. South-North Water Transf. Water Sci. Technol. 2012, 10, 44-51. 
23. Liu, X.Q.; Wang, N.L.; Yao, T.D.; Xu, B.Q.; Zhao, H.B.; He, J.Q.; Guo, X.J. Carbonaceous aerosols in snow and ice in the Tibetan plateau. Earth Sci. Front. 2006, 13, 335-341.

24. Clarke, A.D.; Noone, K.J. Soot in the Arctic snowpack: A cause for perturbations in radiative transfer. Atmos. Environ. 1985, 19, 2045-2053. [CrossRef]

25. Doherty, S.J.; Warren, S.G.; Grenfell, T.C.; Clarke, A.D.; Brandt, R.E. Light-absorbing impurities in Arctic snow. Atmos. Chem. Phys. 2010, 10, 11647-11680. [CrossRef]

26. Warren, S.G.; Clarke, A.D. Soot in the Atmosphere and Snow Surface of Antarctica. J. Geophys. Res. Atmos. 1990, 95, 1811-1816. [CrossRef]

27. Aoki, T.; Kuchiki, K.; Niwano, M.; Kodama, Y.; Hosaka, M.; Tanaka, T. Physically based snow albedo model for calculating broadband albedos and the solar heating profile in snowpack for general circulation models. J. Geophys. Res. Atmos. 2011, 116, D11114. [CrossRef]

28. Chylek, P.; Johnson, B.; Damiano, P.A.; Taylor, K.C.; Clement, P. Biomass burning record and black carbon in the GISP2 Ice Core Geophys. Res. Lett. 1995, 22, 89-92. [CrossRef]

29. Chylek, P.; Srivastava, V.; Cahenzli, L.; Pinnick, R.G.; Dod, R.L.; Novakov, T.; Cook, T.L.; Hinds, B.D. Aerosol and graphitic carbon content of snow. J. Geophys. Res. Atmos. 1987, 92, 9801. [CrossRef]

30. Dasch, J.M.; Cadle, S.H. Atmospheric Carbon Particles in the Detroit Urban Area: Wintertime Sources and Sinks. Aerosol Sci. Technol. 1989, 10, 236-248. [CrossRef]

31. Fily, M.; Bourdelles, B.; Dedieu, J.P.; Sergent, C. Comparison of in situ and Landsat Thematic Mapper derived snow grain characteristics in the alps. Remote Sens. Environ. 1997, 59, 452-460. [CrossRef]

32. Kang, S.C.; Zhang, Y.L.; Qian, Y.; Wang, H.L. A review of black carbon in snow and ice and its impact on the cryosphere. Earth-Sci. Rev. 2020, 210, 103346. [CrossRef]

33. Doherty, S.J.; Dang, C.; Hegg, D.A.; Zhang, R.D.; Warren, S.G. Black carbon and other light-absorbing particles in snow of central North America. J. Geophys. Res.-Atmos. 2014, 119, 12807-12831. [CrossRef]

34. Forsström, S.; Ström, J.; Pedersen, C.A.; Isaksson, E.; Gerland, S. Elemental carbon distribution in Svalbard snow. J. Geophys. Res. 2009, 114, D19112. [CrossRef]

35. Tang, X.G.; Liu, D.W.; Zhang, B.; Du, J.; Lei, X.C.; Zeng, L.H.; Wang, Y.D.; Song, K.S. Research on Hyperspectral Remote Sensing in Monitoring Snow Contamination Concentration. Spectrosc. Spectr. Anal. 2011, 31, 1318-1321.

36. Flanner, M.G.; Liu, X.; Zhou, C.; Penner, J.E.; Jiao, C. Enhanced solar energy absorption by internally-mixed black carbon in snow grains. Atmos. Chem. Phys. 2012, 12, 4699-4721. [CrossRef]

37. Namazi, M.; Salzen, K.V.; Cole, J.N.S. Simulation of black carbon in snow and its climate impact in the Canadian Global Climate Model. Atmos. Chem. Phys. 2015, 15, 18839-18882. [CrossRef]

38. Huang, J.; Fu, Q.; Zhang, W.; Wang, X.; Zhang, R.; Ye, H.; Warren, S.G. Dust and Black Carbon in Seasonal Snow Across Northern China. Bull. Am. Meteorol. Soc. 2011, 92, 175-181. [CrossRef]

39. Negi, H.S.; Kokhanovsky, A. Retrieval of snow albedo and grain size using reflectance measurements in Himalayan basin. J. Cryosphere 2011, 5, 203-217. [CrossRef]

40. Negi, H.S.; Kokhanovsky, A. Retrieval of snow grain size and albedo of western Himalayan snow cover using satellite data. $J$. Cryosphere 2011, 5, 831-847. [CrossRef]

41. Wei, Y.R. Remote Sensing Inversion and Spatiotemporal Variation of Black Carbon and Snow Grain Size in Typical Snow Regions of China Based on MODIS Data. Master Thesis, Lanzhou Jiaotong University, Lanzhou, China, June 2020.

42. Pan, H.Z.; Wang, J.; Li, H.Y. Retrieval Snow Albebo Using MODIS based on the ART Model. J. Remote Sens. Technol. Appl. 2015, 30, 1059-1065. [CrossRef]

43. Shi, Y.F. Glaciers and the Environment in China: Present, Past and Future, 1st ed.; Science Press: Beijing, China, 2000.

44. Chen, G.Y.; Li, D.L. Temporal-Spatial characteristics of Cumulative Snow Depth in Northeast China and Its vicinity. Meteorol. Mon. 2011, 37, 513-521.

45. Che, T.; Li, X. Spatial distribution and temporal variation of snow water resources in china during 1993-2002. J. Glaciol. Geocryol. 2005, 27, 64-67.

46. Ogren, J.A.; Charlson, R.J.; Groblicki, P.J. Determination of elemental carbon in rainwater. Anal. Chem. 1983, 55, 1569-1572. [CrossRef]

47. Grenfell, T.C.; Doherty, S.J.; Clarke, A.D.; Warren, S.G. Light absorption from particulate impurities in snow and ice determined by spectrophotometric analysis of filters. Appl. Opt. 2011, 50, 2037-2048. [CrossRef]

48. Xin, W.; Doherty, S.J.; Huang, J. Black carbon and other light-absorbing impurities in snow across Northern China. J. Geophys. Res. Atmos. 2013, 118, 1471-1492.

49. Hall, D.K.; Salomonson, V.V.; Riggs, G.A. Development of Methods for Mapping Global Snow Cover Using Moderate Resolution Imaging Spectroradiometer Data. Remote Sens. Environ. 1995, 54, 127-140. [CrossRef]

50. Hall, D.K.; Riggs, G.A.; Salomonson, V.V.; DiGirolamo, N.E.; Bayr, K.J. MODIS snow-cover products. Remote Sens. Environ. 2002, 83, 181-194. [CrossRef]

51. Li, Y.; Feng, X.Z.; Xiao, P.F.; Ye, N. Estimating per-pixel snow cover fraction from MODIS in typical area of Bayanbulak. J. Nanjing Univ. 2015, 51, 1022-1029. 
52. Shao, D.H.; Li, H.Y.; Wang, J.; Hao, X.H.; Wang, R.K.; Ma, Y. Retrieval of Snow Albedo based on Multi-source Remote Sensing Data. Remote Sens. Technol. Applic. 2017, 32, 71-77.

53. Hao, X.H.; Wang, J.; Li, H.Y. Evaluation of the NDSI Threshold Value in Mapping Snow Cover of MODIS-A Case Study of Snow in the Middle Qilian Mountains. J. Glac. Geocryol. 2008, 30, 132-138.

54. Kokhanovsky, A.A.; Aoki, T.; Hachikubo, A.; Hori, M.; Zege, E.P. Reflective properties of natural snow: Approximate asymptotic theory versus in situ measurements. IEEE Trans. Geosci. Remote Sens. 2005, 43, 1529-1535. [CrossRef]

55. Kokhanovsky, A.A.; Zege, E.P. Scattering optics of snow. Appl. Opt. 2004, 43, 1589-1602. [CrossRef] [PubMed]

56. Kokhanovsky, A.; Rozanov, V.V.; Aoki, T.; Odermatt, D.; Brockmann, C.; Krüger, O.; Bouvet, M.; Drusch, M.; Hori, M. Sizing snow grains using backscattered solar light. Int. J. Remote Sens. 2011, 32, 6975-7008. [CrossRef]

57. Kokhanovsky, A.; Schreier, M. The determination of snow specific surface area, albedo and effective grain size using AATSR space-borne measurement. Int, J Remote. Sens. 2009, 30, 919-933. [CrossRef]

58. Zhao, C.; Hu, Z.; Qian, Y.; Ruby Leung, L.; Huang, J.; Huang, M.; Jin, J.; Flanner, M.G.; Zhang, R.; Wang, H.; et al. Simulating black carbon and dust and their radiative forcing in seasonal snow: A case study over North China with field campaign measurements. Atmos. Chem. Phys. 2014, 14, 11475-11491. [CrossRef]

59. Lv, X.; Xu, J.H.; Deng, K. Analysis of Temporal-Spatio Distribution of Annual Aerosol Optical Depth of Anhui Province. Environ. Sci. Technol. 2017, 40, 209-216.

60. Zhang, J.; Yuan, X.D.; Lin, H. The Extraction of Urban Built-up Areas by Integrating Night-time Light and POI Data-A Case Study of Kunming, China. IEEE Access 2021, 9, 22417-22429.

61. Li, J.F.; Pan, J.H. Spatial expansion of cities at county-level or above in Gansu Province from 1992 to 2012 based on DMSP nighttime light images. J. Glaciol. Geocryol. 2016, 38, 829-835.

62. Bi, X.Y.; Liu, F.; Chen, H.; Wu, D.; Deng, X.J.; Huang, J. Vertical Distribution Features of Atmospheric Stability over Beijing Area. J. Trop. Meteorol. 2003, 19, 173-179.

63. Grenfell, T.C.; Light, B.; Sturm, M. Spatial distribution and radiative effects of soot in the snow and sea ice during the SHEBA experiment. J. Geophys. Res. Ocean. 2002, 107, SHE 7-1-SHE 7-7. [CrossRef]

64. Grenfell, T.C.; Warren, S.G.; Radionov, V.F.; Makarov, V.N.; Zimov, S.A. Expeditions to the Russian Arctic to Survey Black Carbon in Snow. Eos. Trans. Am. Geophys. Union 2013, 90, 386-387. [CrossRef]

65. McConnell, J.R.; Edwards, R.; Kok, G.L.; Flanner, M.G.; Zender, C.S.; Saltzman, E.S.; Banta, J.R.; Pasteris, D.R.; Carter, M.M.; Kahl, J.D.W. 20th-Century Industrial Black Carbon Emissions Altered Arctic Climate Forcing. Science 2007, 317, 1381-1384. [CrossRef] [PubMed]

66. Kaspari, S.; McKenzie Skiles, S.; Delaney, I.; Dixon, D.; Painter, T.H. Accelerated glacier melt on Snow Dome, Mount Olympus, Washington, USA, due to deposition of black carbon and mineral dust from wildfire. J. Geophys. Res. Atmos. 2015, 120, $2793-2807$. [CrossRef]

67. Ming, J.; Xiao, C.D.; Du, Z.C.; Flanner, M. Black Carbon in Snow/Ice of West China and Its Radiative Forcing. Adv. Clim. Chang. Res. 2009, 5, 328-335.

68. Wang, M.; Xu, B.Q.; Wu, G.J.; Yang, W. Carbonaceous Aerosols Recorded in Ice Core in Southeastern Tibetan Plateau. Adv. Clim. Chang. Res. 2010, 6, 175-180.

69. Xin, W.; Wei, P.; Yong, R.; Zhang, X.; Zhang, X.; Shi, J.; Jin, H.; Dai, M.; Chen, Q. Observations and model simulations of snow albedo reduction in seasonal snow due to insoluble light-Absorbing particles during 2014 Chinese survey. Atmos. Chem. Phys. 2017, 17, 2279-2296. 